\title{
IMPLEMENTATION OF REGIONAL TAX POLICY: A STUDY ON HOTEL TAXATION FOR BOARDINGHOUSES CATEGORY STIPULATED ON REGIONAL REGULATION OF CITY OF PALANGKA RAYA NUMBER 21 OF 2014 ON REGIONAL TAX AND RETRIBUTION BOARD OF CITY OF PALANGKA RAYA
}

\author{
Sintha Melia*, Saleh Choirul, Suryadi \\ Faculty of Administrative Science, University of Brawijaya, Indonesia \\ *E-mail: meliasintha.ms@gmail.com
}

\begin{abstract}
This study aims to analyze the implementation of tax policy in the City of Palangka Raya, Central Borneo, as stipulated in the Regional Regulation of Palangka Raya Number 21 of 2014 by analyzing the inhibiting and supporting factors in this matter, in addition to the target and realization of tax policy on boardinghouses in the City of Palangka Raya. The regulation was enacted with the intention to generate regional revenue from potential boardinghouses through tax policy. This research employed descriptive research through qualitative approach. In measuring the implementation of the tax policy in the City of Palangka Raya particularly on boardinghouses, Grindle Implementation Model (1980) was employed which consists of content, context, and policy results. The findings indicate that the society has low understanding upon the tax policy on boardinghouses as there are many business owners running boardinghouses whom have not been registered as taxpayers. In addition, the business owners of the property and tenants have complained with the high tax services of $10 \%$. As projected target of this tax policy has increased, it is in contrary with the awareness of the society on the tax policy which in turn affects the realization of the target. Some factors may affect the realization of the tax policy, such as social and economic conditions as the supporting factors. Meanwhile, the constraints in this policy are the low awareness and knowledge of the community which causes such traditional direct approach for tax collection and social resources. Therefore, the implementation of tax policy on boardinghouses in the City of Palangka Raya as stipulated in the Regional Regulation of Palangka Raya Number 21 of 2014 needs more concern for maximum results.
\end{abstract}

\section{KEY WORDS}

Policy implementation, local tax, house board tax.

In Indonesia, local government both provincial and municipal governments have the authority to impose regional taxes and retribution in their own respective region, despite the fact the amount of revenue is still relatively small compared to national tax revenues. The regional tax and retribution system employed so far has some weaknesses, particularly in terms of the imbalanced benefits for the community and the amount of tax bills being charged. Therefore, the emerging supervision upon the implementation of regional taxes and retribution is called by the term "close-list system". According to Ismail (2013: 38-39), closelist system can be interpreted as a way of limiting the list or the number of a selected object. In the context of collecting taxes and levies or retribution, it can be interpreted as limiting the number of types of taxes or charges to the users that can be enforced as levies and can be collected by the regional authority.

Based on the background, it is then associated with one of the tax-related policies i.e. tax policy on boardinghouses. The policy has an obstacle as it stated in Article 2 paragraph (3) of Law Number $28 / 2009$, stating that the Regional Government is prohibited to levy taxes other than the type of taxes as mentioned above as one regulation should not conflict with higher regulations. Nevertheless, the City Government of Palangka Raya published Regional Regulation of Palangka Raya Number 21 of 2014 on Hotel Tax, of which contains one tax object that is a boardinghouse with the number of rooms of 10 or more. Another 
consequence that may arise from this regulation is the reaction from the community either as a owners of boardinghouses business or as service users or tenants.

The regional regulation of the tax on boardinghouses is expected to not only focus on the local government's revenue, but all parties namely the business owners and service users through clear and fair goals and objectives stated in the regulation. In one hand, this tax regulation has positive impact on increasing the revenue for the region. On the other hand, the process of this policy ultimately should not become one more burdensome policy for the community as the targets of the tax policy. Upon this issue, the paper is intended to elaborate the implementation of the regional regulation of the tax policy on boardinghouses.

\section{LITERATURE REVIEW}

In this study, the theory related public policy becomes the main literature, according to Sueuer \& Sunkin in Nugroho (2012: 40) that public policy is a color that pour upstream of a river. If we pour red color, the river will turn to red. If we pour poison, everybody who drinks the water will be poisoned. Public policy is the rules of the game, in any society as a political entity.

The significant influence of certain policy to the community lives illustrates how important the implementation process of the policy. Therefore, it is necessary to measure and assess the policies being implemented in the community. The theory used to measure the regional tax policy in City of Palangka Raya was theory of Grindle Implementation Model (1980) which consists of three main contents, namely 1) policy content (including the interests of targeted groups, benefit types, degree of desired changes, location of decision, program implementer, and source), (2) policy results (including the impacts on the communities, individuals and groups, as well as changes and acceptance of the community upon the policy), and 3) policy context (including the power, interests, and strategies of actors or stakeholders involved, characteristics of ruling institutions and regimes).

\section{METHODS OF RESEARCH}

This is a descriptive research with qualitative approach. There are some focuses of this research, namely 1) the implementation of Regional Tax Policy of City of Palangka Raya Number 21 of 2014 on Hotel Tax of Boardinghouse Category. The policy was then assessed by using Grindle Implementation Model, covering a) policy content, b) policy context, c) policy result; 2) factors supporting and inhibiting the tax policies in the City of Palangka Raya; and 3) projected target and realization of the tax policies in the City of Palangka Raya. The research was conducted in City of Palangka Raya with the research site at the Regional Tax and Retribution Board (BPPRD) of City of Palangka Raya.

The data used were both primary and secondary data. The primary data were collected from interviews with relevant informants, while the secondary data were referred to some relevant documents, e.g. regulation documents and reports. Data sources in this study involved relevant stakeholders as the key informants, events, and documents. Data collection was conducted by direct observation, in-depth interview, and documentation. The research instruments consist of the researchers as the key instrument, field notes, interview guideline, and documentation. Data analysis techniques in this research was adapted from the technique proposed by lan Dey (1993), that data analysis involves three interconnected processes, i.e. describing, classifying, and connecting processes.

\section{RESULTS AND DISCUSSION}

The Implementation of the Regional Tax Policy of City of Palangka Raya Number 21 of 2014 on Hotel Tax with Boardinghouses Category.

Policy content:

a) The interest of targeted groups. In the implementation of this tax policy, there is a miscommunication between the owners of the boardinghouses as a tax subject-a person or 
an entity that runs the hotel, guesthouse, boardinghouses, and lodgings starting from 10 rooms and more and the service users or tenants-people who rent the boardinghouses or rooms. The consequence of this miscommunication is who should be responsible for paying the taxes, whether the business owners or the service users. If we refer to the Regional Regulation of City of Palangka Raya Number 21 of 2014, the subject of the taxation mentioned is the person or entity that runs the hotel, guesthouses, lodgings, and boardinghouses. Meanwhile, the charging rate for the services is $10 \%$ of the amount of payment should be paid by the service users to the business owners. It cannot be denied that service users of the boardinghouses are mostly students, and this policy brings negative reactions.

b) Types of benefits. The benefits of the tax policy on boardinghouses is basically not instantly felt directly by the community, since managing tax is not easy and requires a long process. However, the function of the tax which needs to be emphasized is that it is a form of community contribution, particularly in the development of City of Palangka Raya.

c) Degree of expected changes. The expected changes by the government in the form of the taxpayer's active attitude and contribution in paying the tax on boardinghouses are not always easy to implement. People in City of Palangka Raya are still lacking in awareness to report their business; even though there has been an initiative to report their business, however, it is not followed by paying the taxes which then results in arrears and penalties of $2 \%$ every month from the amount of tax paid. Self-assessment system used to facilitate and give confidence to the society, in fact, has such deficiency. This system is dependent on people's awareness, which might result in abuse in the form of a lack of awareness.

d) Decision-making authority. The process of decision-making in this tax policy on boardinghouses is under the authority of the City Mayor of Palangka Raya who then coordinates with Regional Tax and Retribution Board (BPPRD) as the appointed department in the implementation of this policy.

e) Program Executors. The implementation of the program in related with the tax policy on boardinghouses is stated in Regional Regulation Number 21 of 2014 is Regional Tax and Retribution Board (BPPRD) of City of Palangka Raya. In implementing this policy, BPPRD of City of Palangka Raya focuses on the management of local taxes and levies in the City of Palangka Raya, including the taxes on boardinghouses.

f) Involved Resources. Resources in the implementation of this tax policy have problems in terms of quantity. BPPRD, as the department which is responsible for this policy, lacks human resources such as the shortage of the tax assessment team, no tax auditors, and no bailiffs.

Policy Context:

a) Power, interest, and strategy of involved actors. The expected power and interest that needs to be realized through the tax policy in the City of Palangka Raya is an increase in regional revenue, especially the City of Palangka Raya. The strategy employed by the government in order to realize the policy is through socialization, cooperation with the districts, and also cooperation with Telkomsel.

b) Characteristics of Agency and Ruling Regime. The success or failure of a policy can be measured through the characteristics of the ruling institution in the implementation of the policy. Cooperation undertaken by BPPRD and the Attorney in the context of educating the public is one of the government's efforts that should be appreciated. This cooperation aims to embrace the public openly and indirectly indicates that BPPRD expects the community as the business owners of the boardinghouses may have understanding and knowledge about this policy; that government does not just require the public to pay taxes without knowing the bases of the tax.

c) Level of Public Compliance and Implementer's Responses. Based on the results of interviews and site observation, there are still several business owners of boardinghouses with more than 10 rooms do not pay taxes. There is even one boardinghouse with a total of 53 rooms belonging to a Member of Parliament (MP) of Palangka Raya that does not pay taxes. The level of public compliance in carrying out the policies, either reporting its business or carrying out obligations as a taxpayer, is still low. This condition is exacerbated by a less 
resolute government responses and sanctions that have no deterrent effects; this policy also creates an unfair impression on taxpayers who actively pay with the ones who never pay taxes at all.

Policy Results:

a) Impact on Society, Individuals, and Groups. This tax policy has an impact on the society and the efforts taken by the taxpayers in order to minimize the tax burden is by raising the rental price which ultimately affects the service users, who are mostly students; these students in this case feel objected to the policy. In addition, there are also business owners of boardinghouses who prefer not to raise rental rates by reason of avoiding any possible protests from the service users.

b) Changes and Acceptance by Society. The tax policy on boardinghouses raises two types of changes after being implemented. There are people who reject this policy, there are also people who accept the policy with the condition that the use and management of taxpayers' money should be done properly and responsibly by the government.

Supporting and Inhibiting Factors:

Supporting factors. Social and economic condition - Students who come from outside the City of Palangka Raya have a role that the idea the tax policy on boardinghouses is potential and should be implemented. In addition, the existence of several universities in the City of Palangka Raya attracts new students every year coming to the city. Moreover, this condition affects broader potentials such as the presence of companies and employment opportunities for employees who come from outside the City of Palangka Raya; this opportunity is also promising. In short, it can be assumed that the tax policy is dependent on the dynamics of community life, which also becomes a supporting factor and potential for the implementation of the tax policy in the city of Palangka Raya.

Inhibiting factors

a) Low awareness and understanding of the society on tax policy on boardinghouses in the City of Palangka Raya. People in developed countries along with their advanced governments certainly have better undertanding and awareness on taxation. The rationale is that in developed countries, the people are not only actively paying taxes, but getting the real evidences; that paying taxes is no longer merely a mere awareness, but it is a real form of solidarity for the progress and prosperity of the state as well as the society. The low awareness from the business owners of boardinghouses in the City of Palangka Raya in paying taxes shows that the understanding upon this policy is still low. In addition, the business owners are the ones who only distribute the taxpayers' money because the real taxpayers are the service users. Thus, in order to address this issue, the government should actively conduct direct approach to the the taxpayers.

b) Lack of Infrastructure. The presence of adequate infrastructure in the implementation of a policy has positive impacts which in turn will facilitate the implementation process. Manual payment system is one of the shortcomings that make the policy of any taxes is considered impractical by the public. The tax policy is of course still able to run even without the presence of sophisticated and practical infrastructures, but the presence of infrastructure certainly becomes positive medium for the tax policy considering the development of the current era that requires everything to run easily, practically, and quickly.

c) Lack of Human Resources:

Table 1 - Target and Realization of Tax on Boardinghouses in Palangka Raya City

\begin{tabular}{|c|c|c|c|}
\hline Budgeting in 2017 & Target in 2017 & Realization & $\%$ \\
\hline December/2014 & $100,000,000$ & $13,523,500$ & 13.52 \\
\hline December/2015 & $1,200,000,000$ & $343,638,310$ & 28.64 \\
\hline December/2016 & $610,000,000$ & $580,052,454$ & 95.09 \\
\hline July/2017 & $1,196,170,000$ & $366,559,518$ & 30.64 \\
\hline
\end{tabular}

The importance of quantity and quality of resources becomes one of inhibiting factors, particularly in the case of lacking of human resources in the implementation of a policy. In relation to the implementation of the tax policy on boardinghouses, BPPRD as the 
designated department suffers from a lack of human resources. Lack of human resources is such as a shortage of tax assessment teams, no tax inspectors and auditors, and no bailiffs.

d) Minimum Socialization. It would be very difficult to make a policy work, if the policy targets do not have understanding upon the policy. In the case of this tax policy, the policy targets, the business owners of boardinghouses do not have knowledge and understanding upon the taxes imposed on their businesses. Based on site observation, there are several business owners of boardinghouses with more than 10 rooms do not know about the tax policy; they admit that there has never been any socialization around this policy. The lack of socialization then raises questions among business owners, regarding the imposition of taxes and benefits and the purpose of imposing such taxes on their businesses.

Target and Realization of the Tax Policy of Boardinghouses in the City of Palangka Raya. If we look at this tax policy positively, the implementation of tax policy on the boardinghouses in City of Palangka Raya could become the potential incomes for the regions in the form of regional revenue (PAD). On the other hand, this tax policy also has impacts in the form of the increasing charging rates of the boardinghouses that imposes the tenants, whom are mostly students who are studying in the city. As the projected regional revenue has increased each year, it is however inversely proportional to the public awareness in reporting their business on boardinghouses as well as their willingness to pay the taxes. In determining taxes and the projected regional revenue (PAD) every year, BPPRD has a team called the Regional Revenue Budgeting Team (TAPD). TAPD is assigned to discuss all forms of targets for taxes, including taxes and fees of boardinghouses in the city. TAPD formulates an increase in revenue target if the community as taxpayers already understand and comply with the depositing the regional tax policies. Unfortunately, the compliance of the public in reporting and paying taxes is still very low, which then impact on the realization of revenue from taxes that never meet the target. The data below illustrates the regional revenue from taxes:

Table 2 - The Regional Revenue From Taxes

\begin{tabular}{|c|c|c|c|}
\hline Budgeting in 2017 & Target in 2017 & Realization & $\%$ \\
\hline January & $1,196,170,000$ & $58,542,690$ & \\
\hline February & $1,196,170,000$ & $55,598,886$ & \\
\hline March & $1,196,170,000$ & $61,009,261$ & \\
\hline April & $1,196,170,000$ & $50,76,261$ & \\
\hline Mat & $1,196,170,000$ & $70,649,465$ & \\
\hline June & $1,196,170,000$ & $54,217,955$ & \\
\hline July & $1,196,170,000$ & $50,023,691$ & \\
\hline August & $1,196,170,000$ & $64,716,395$ & \\
\hline September & $1,196,170,000$ & $61,398,152$ & \\
\hline October & $1,196,170,000$ & $57,175,600$ & \\
\hline November & $1,196,170,000$ & $63,089,052$ & $59.09 \%$ \\
\hline December & $1,196,170,000$ & $59,551,419$ & \\
\hline Total & & $706,848,827$ & \\
\hline
\end{tabular}

\section{CONCLUSION}

The implementation of tax policy of boardinghouses in the City of Palangka Raya is still not maximal. One important factor that causes this condition is the low awareness and lack of knowledge on the tax policy, so mechanism of taxation is executed directly to the taxpayers. In addition to the inhibiting factors, lack of infrastructures and lack of socialization become the inhibiting factors to the implementation of the tax policy. With the high target of regional revenue from tax also contributes to the unmet realization of tax policy of boardinghouses in the City of Palangka Raya.

Recommendation. The government needs to disseminate to the public as the tax payers as well as service users of the boardinghouses regarding this tax policy. In addition, the government also needs to set the sanctions that provide such deterrent effects in case non-compliance is made by the taxpayers. All forms of aspirations from the society also need 
to be considered as a form of good communication. Lastly, realistic target setting also needs to be evaluated by the government as the implementation of the tax policy is dependant on the dynamic social conditions and awareness of the taxpayers.

\section{REFERENCES}

1. Dey, I. (1993). Qualitative Data Analysis A User-Friendly Guide for Social Scientists. New York: Roudledge.

2. Grindle, M. S. (1980). Politics and Policy Implementation in The Third World. New Jersey: Princetown University Press.

3. Ismail, T. (2013). Analisis dan Evaluasi tentang Pajak dan Retribusi Daerah. Badan Pembinaan Hukum Nasional Kementerian Hukum dan Hak Asasi Manusia RI.

4. Nugroho, R. (2012). Public Policy for The Developing Countries. Yogyakarta: Pustaka Pelajar.

5. Peraturan Daerah Kota Palangka Raya Nomor 21 Tahun 2014

6. Undang-Undang Republik Indonesia Nomor 28 Tahun 2009 